\title{
How Important are Debt and Growth Expectations for Interest Rates?
}




\section{WP/15/94}

\section{IMF Working Paper}

\section{How Important are Debt and Growth Expectations for Interest Rates?}

by Sohrab Rafiq 


\title{
IMF Working Paper
}

Asia and Pacific Department

\section{How Important are Debt and Growth Expectations for Interest Rates? Prepared by Sohrab Rafiq ${ }^{1}$}

\author{
Authorized for distribution by David Cowen
}

April 2015

\begin{abstract}
This Working Paper should not be reported as representing the views of the IMF. The views expressed in this Working Paper are those of the author(s) and do not necessarily represent those of the IMF or IMF policy. Working Papers describe research in progress by the author(s) and are published to elicit comments and to further debate.

This paper uses a dataset on private-sector risk aversion as well as expectations of long-run growth and debt to explain trends in implied forward rates on government bonds in the G-7 countries. The results show, consistent with the literature, that a one-percent rise in the long-run projected debt-to-GDP ratio causes an increase in bond yields of a relatively modest 1-to-6 basis points. Shocks to growth expectations and risk aversion have been comparatively more successful in explaining the behavior of long-term rates. The findings imply that growth policies rather than long-run projections of fiscal outcomes may be more important in helping influence long-term borrowing costs.
\end{abstract}

JEL Classification Numbers: E52, E62, F41

Keywords: public debt, economic growth, expectations, time-variation Author's E-Mail Address: $\quad$ srafiq@,imf.org

\footnotetext{
${ }^{1}$ The author wishes to thank seminar participants from the Fiscal Affairs Department and Asia and Pacific Department, Abdelhak Senhadji, David Cowen, Todd Mattina, Paul Cashin, Stephan Danninger, Koshy Mathai, Ravi Balakrishnan, Kotaro Ishi, To-Nhu Dao and Selim Ali Elekdag. The usual disclaimer applies.
} 


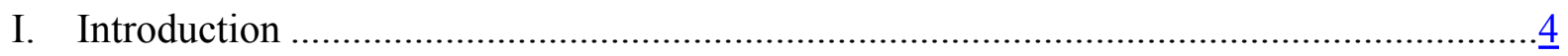

II. A Debt Expectations and Interest Rate Model ....................................................

III. Expected Debt and Long-Term Implied Forward Rates.............................................. $\underline{8}$

IV. Explaining Movements in Forward Interest Rates .............................................. 11

A. Can Debt Expectations Explain the Variance of the Yield Curve ..........................12

B. Information in Private Sector Debt Expectations for Forward Interest Rates.......... $\underline{16}$

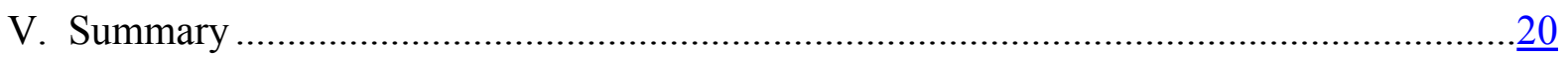

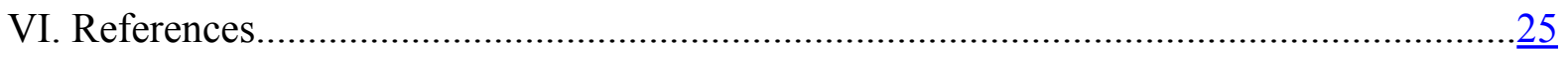

\section{Figures}

1. Five Year Growth and Debt Expectations

2. Scatter Plot of Five Year Debt and Growth Expectations ............................................. $\frac{7}{7}$

3. Scatter Plot of Five Year Debt Expectations and the Forward Term Spread ......................

4. Coefficient Between Forward Rates and Debt Expectations ........................................10

5. Size of Macroeconomic Expectation Shocks..................................................... 13-15

6. Relative Contribution of Macro Expectations to Term Spread ................................. 18-20

\section{Appendixes}

A. Linking the Term Spread and Fiscal Position .......................................................

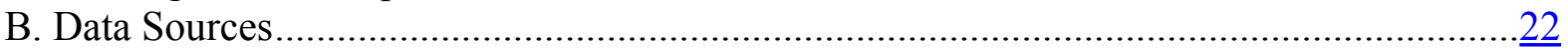

C. Time-varying Regression Estimation ................................................................ 


\section{INTRODUCTION}

Since the start of the global financial crisis (GFC) in 2008, long-term interest rates have experienced sizable fluctuations; while there have also been upward revisions in private sector expectations of the long-run public debt trajectory (Figure 1). Upticks in market interest rates were often followed by reports predicting rising fears about debt sustainability. An alternate view, however, attributes the variations in rates to fluctuating optimism regarding the prospects for economic recovery, with long-run private sector growth expectations revised downward following the crisis. This paper uses qualitative cross-country data to quantify the variation in long-term rates that can be explained by unexpected upward revisions in long run private sector debt and growth expectations.

\section{Figure 1. Five Year Real GDP Growth and Debt Expectations}
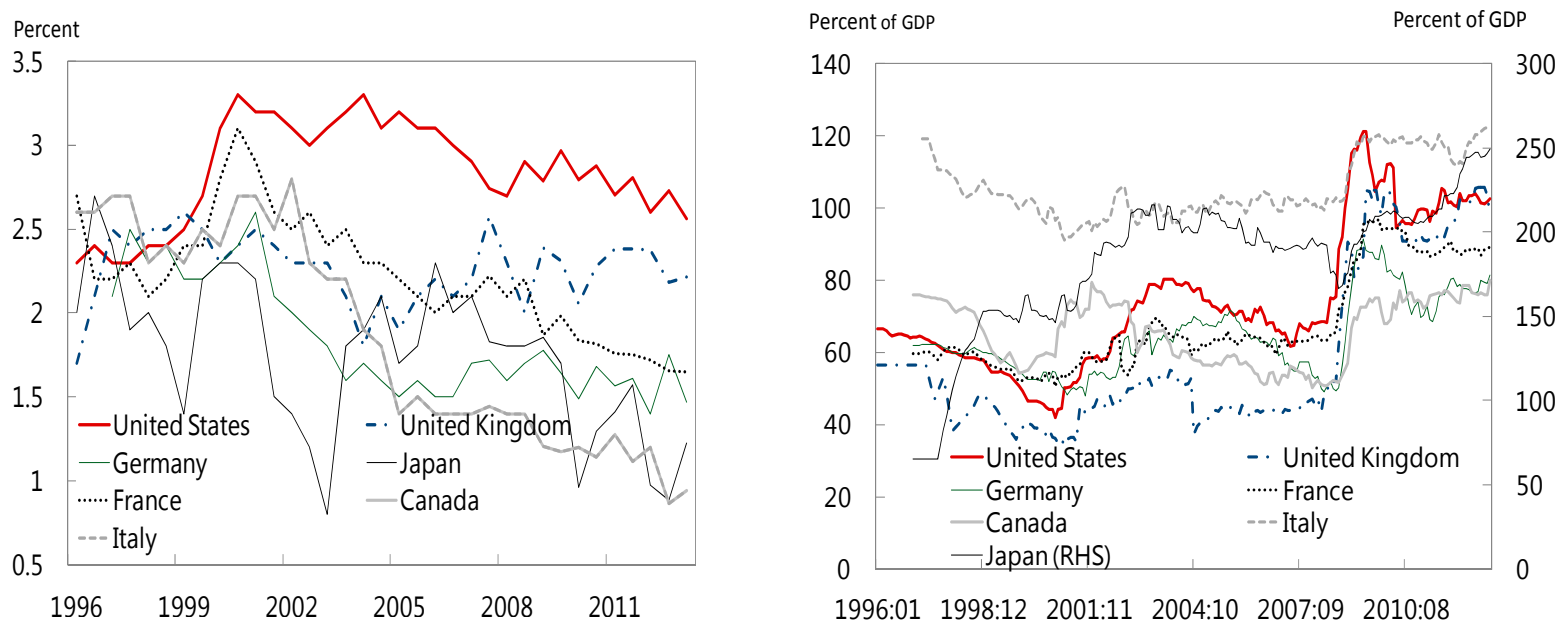

Source: Consensus Forecast and EIU

Market interest rates assimilate information about the economy. Understanding the role of debt expectations on interest rates could help policymakers anchor questions of fiscal sustainability. If interest rates are driven by investors' forecasts of public debt, which are themselves characterized by self-fulfilling prophecies resulting from a sticky-information environment, then the effectiveness of fiscal consolidation efforts in reducing borrowing costs could fall as agents fail to correctly observe actual economic fundamentals. The authorities may be able to convince agents that future sovereign risks have fallen by engaging in sizeable fiscal adjustment, but at the potential cost of slower economic growth.

Many macro models assume expectations to remain relatively fixed in the long-run. Expectations that are expected to prevail in the future are, therefore, assumed to be less affected by information about the state of the current business cycle, which helps reduce reverse-causality effects induced by countercyclical policies and automatic fiscal stabilizers. Debt expectations projected several years into the future are, therefore, more 
informative about the longer-run fiscal position and viewed as a better approximation of private sector concerns about debt sustainability.

A number of findings are reported. First, interest rates are moved by a confluence of expectation shocks at any one particular time. Second, the explanatory power of long-run growth expectations for forward rates rose during crisis periods. Finally, post-GFC changes in the expectations of economic growth and shocks to risk preference, which signify a change in the willingness of investors to bear risk, were more significant than long-term private sector debt projections in transmitting the effects of the 2008-09 crisis to long-term forward interest rates. These findings are also illustrated for high debt Italy and Japan. The findings should not be construed as implying that debt does not matter, since changes in long-run debt expectations manifest in a small but significant magnitude at the long-end of the yield curve. Even so, policies which directly influence long-run growth expectations are relatively more important than long-run projected fiscal outturns in helping determine government borrowing costs.

The paper is organized as follows: Section 2 lays out a simple debt expectations-interest rate model, including the structural identification scheme and data definitions. Sections 3 and 4 discuss the results from the model, with Section 5 concluding.

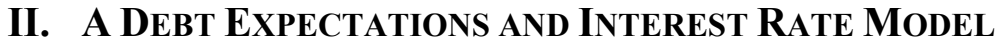

This paper measures long-term macroeconomic trends by using long-run forecasts of the economy from surveys of professional forecasters. Market prices provide timely information on policy expectations, but can deviate from investors' expectations of the most likely path because they embed risk premiums. Survey data, as used here, acts as an independent source of information removing a source of ambiguity that has plagued the empirical literature. The rationale is that professional forecasters are able to consider a range of information on the economy - some outside the scope of simple models - to assess long-term relationships. In the event, it raises the probability of uncovering deeper structural relationships between expectations and long-term rates.

\section{Model and data description}

This paper uses high frequency monthly data running from 1996:1 to 2013:1. A parsimonious specification is adopted that is based on a generalized version of reduced form models that link debt and interest rates. ${ }^{2}$ It is specified as follows:

$$
i_{t}^{5}-i_{t}^{1}=\beta_{0}+\beta_{1} \pi_{t+h \mid t}^{e}+\beta_{2} d_{t+h \mid t}^{e}+\beta_{3} y_{t+h \mid t}^{e}+\beta_{4} e_{t}+u_{t}
$$

\footnotetext{
${ }^{2}$ See Feldstein (1986); Canzoneri, Cumby, and Diba (2002); Kitchen (2002); Laubach (2009); and Kitchen and Chinn (2011).
} 
where $i_{t}^{5}$ and $i_{t}^{1}$ is the nominal implied forward five and one year interest rates, $d_{t+h \mid t}^{e}$ is the change in the expected debt-to-GDP ratio, $y_{t+h \mid t}^{e}$ and $\pi_{t+h \mid t}^{e}$ is a measure of long-run expected GDP growth and inflation, and $e_{t}$ is a measure of risk aversion. Expectations are derived from a long-term horizon of five years $(h=5)$, which is sufficiently forwardlooking to strip out short-run business cycle dynamics. ${ }^{3}$ To the extent the model includes forward-looking fundamentals that drive debt expectations, such as growth expectations, the probability that the identified debt expectations shock is exogenous is higher than in models which do not capture broader macro expectations.

In assessing the effects of debt on interest rates, Gale and Orzag (2002), Canzoneri, Cumby, and Diba (2002), Kitchen (2002) and Kitchen and Chinn (2011) note it may be more insightful to examine the term spread between long- and short-term rates. ${ }^{4}$ This paper does such, too, but constructs the term spread using the implied near-term (one year) forward rate and implied forward five year rate $\left(i_{t}^{5}-i_{t}^{1}\right)$. The compressed yield curve since 2009 has raised the usefulness of forward rates as an analytical device. ${ }^{5}$ Gürkaynak, Sack, and Swanson (2005) and Gürkaynak, Sack, and Wright (2007) note that more information can be extracted from the yield curve by using forward rates, since near-term forward rates are primarily affected by monetary policy expectations and hence cyclical variables, while longer-term forward rates are determined by long-run macroeconomic fundamentals or changes in risk preferences, with long-term interest rates conflating these two influences. In addition to controlling for monetary policy shifts and cyclical factors, the forward term spread helps avoid having to model the level of interest rates, which VAR models tend to do poorly in as highlighted in Gale and Orzag's (2002) review of the literature.

Other variables in the paper are defined as follows:

- $\quad \bar{y}_{t+5 \mid t}^{e}$ is the average five-year ahead forecast of real GDP. It is based on the median projected GDP growth taken from Consensus Forecast data. ${ }^{6}$

- $\quad \pi_{t+5 \mid t}^{e}$ five year ahead inflation expectations. It is included to control for the effect of monetary policy on the long-term interest rate.

- $\quad d_{t+5 \mid t}^{e}$ captures the private sector's expectations of the future debt trajectory over a five year horizon. ${ }^{7}$ It accounts for the forward-looking component of debt

\footnotetext{
${ }^{3}$ See Barksy and Sims (2013).

${ }^{4}$ See Appendix A for a simple two-period model linking public debt and the term spread.

${ }^{5}$ See Gürkaynak and Wright (2012) and Benati and Baumeister (2013).

${ }^{6}$ Since these data are only available semi-annually, they are extrapolated into higher frequencies using the one year ahead Consensus Forecast, which is available monthly, and Kalman smoothing via a state-space model.

${ }^{7}$ Elmendorf and Mankiw (1999) and Engen and Hubbard (2005) show in a neo-classical framework that a rise in the debt-to-GDP ratio is associated with an increase in interest rates, even if there is only partial crowding out effects.
} 
dynamics for interest rates. The data on long-run private sector debt expectations are from the Economic Intelligence Unit (EIU). ${ }^{8}$

- $\quad e_{t}$ measures the risk premium, and accounts for the covariation between interest rates and macroeconomic expectations. With no agreed method for deriving the term premium, this paper follows the approach set out in Laubach (2009), which observed the equity premium - used as a proxy for risk aversion - to be an important factor affecting the relationship between expected debt levels and interest rates. ${ }^{9}$ The model includes a measure of the equity premium based on the Gordon (1962) growth model of stock valuation, which equates to an expression for the rate of return on equity adjusted by the return on long-term government bonds.

\section{Figure 2. Scatter Plot of Five Year Debt Expectations and Five Year Growth Expectations}

Figure 3. Scatter Plot of Five Year Debt Expectations and the Forward Term Spread

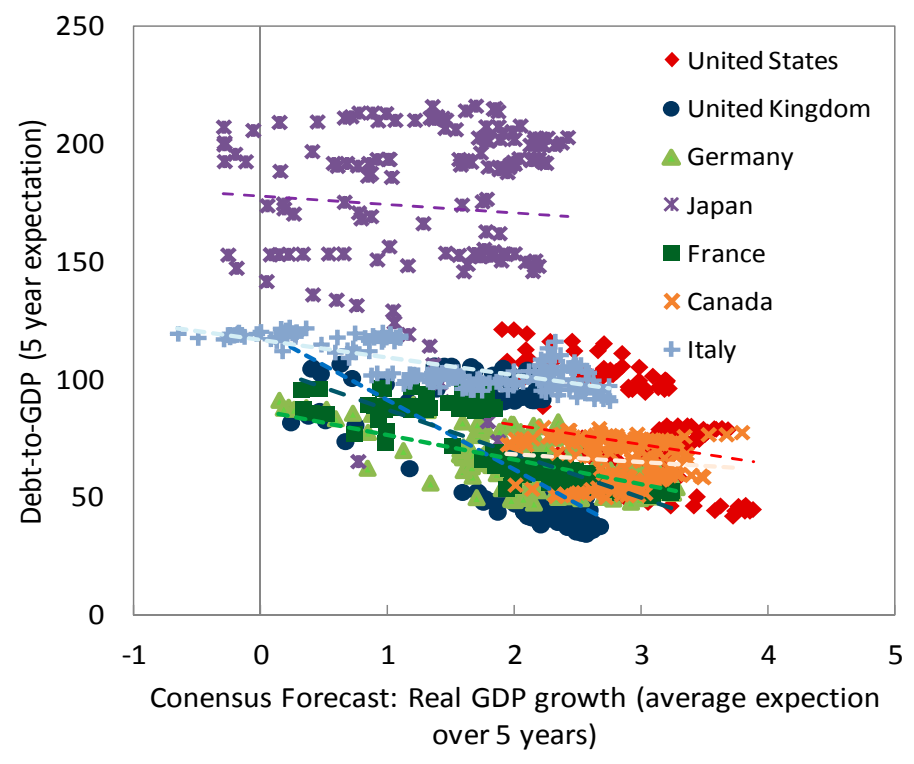

Source: EIU and Consensus forecast

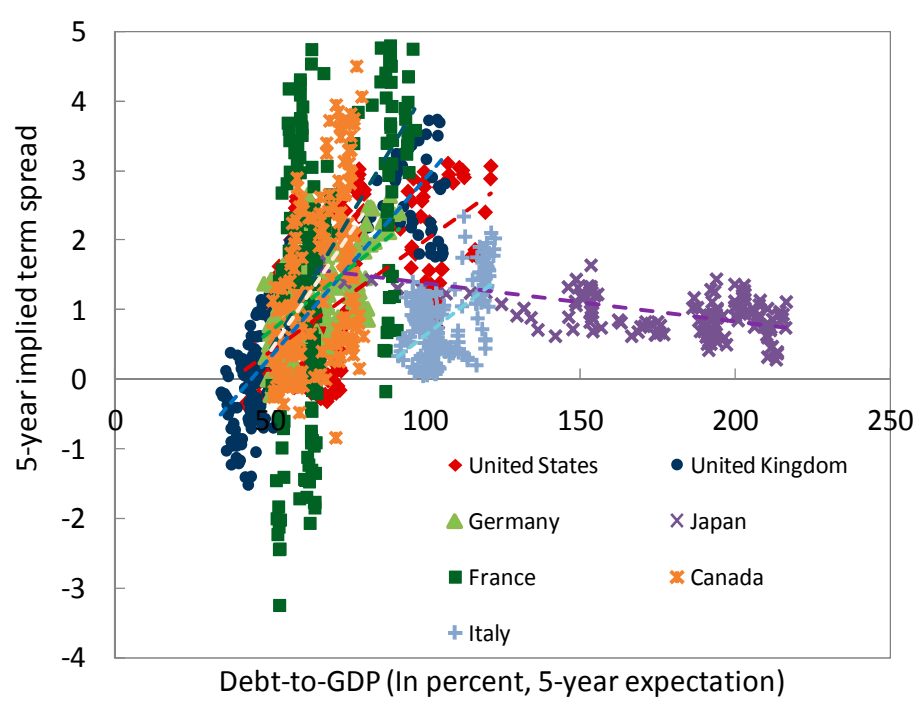

Source: EIU and Staff calculations

Scatter plots illustrate the five-year debt expectations vis-à-vis five-year growth expectations and term spread (Figures 2 and 3). Higher projected debt is associated with higher interest rate spreads for all countries except Japan, and is negatively correlated with long-term expected growth.

\footnotetext{
${ }^{8}$ The sole use of EIU data to capture median evolution of debt dynamic expectations need not necessarily be problematic. First, the mixing up of sources to attain survey data should help account for heterogeneity among agents' expectations. Second, Carroll (2001) and Mankiw, Reis, and Wolfers (2003) report that the general public's expectations tend to respond to the professionals' expectations, and are thus closely intertwined.

${ }^{9}$ See Bauer and Rudebusch (2013).
} 


\section{EXPECTED DEBT AND LONG-TERM IMPLIED FORWARD RATES}

In order to explore the reduced-form interest rate-debt expectation relationship across macroeconomic regimes, regression equation (1) is estimated using a state-dependent model. The use of a time-variation coefficient model is more preferable than assuming discrete breaks, since changes to private sector expectations tend to be smooth due to aggregation. The presence of learning by agents also favors 'smooth and continuous drifting coefficients' over a model with discrete breaks. The use of a non-constant parameter model follows recent term structure models, which incorporate the idea that investors learn slowly about structural change. ${ }^{10}$ The coefficients in (1) are therefore assumed to evolve according to the following law of motion equation:

$$
\beta_{t}=\beta_{t-1}+v_{t} \quad v_{t} \sim N(0, Q)
$$

It is assumed that agents observe current and past realizations of the state of the macroeconomy, which forms a one-step-ahead prediction error $\left(v_{t}\right)$. The smoothed coefficient values are estimated by filtering backward and drawing coefficients at each date $t-1$ conditioned on period $t\left(f\left(X_{t} \mid t-1\right)\right)$, as in Durbin and Koopman (2002).

In order to account for uncertainty in macroeconomic expectations it is assumed that shocks to expectations have time-varying variance. ${ }^{11}$ Equation (1) allows for heteroskesdastic disturbance terms, expressed as:

$$
\varepsilon_{t}=\frac{\sqrt{h_{t}}}{2} \xi_{t}, \quad \xi_{t} \sim N\left(0, \sigma_{\xi}^{2}\right)
$$

where the stochastic volatility component $\left(h_{t}\right)$ is assumed to evolve as a driftless random walk, or:

$$
h_{t}=\lambda h_{t-1}+\eta_{t}, \eta_{t} \sim N\left(0, \sigma_{\eta}^{2}\right)
$$

The self-fulfilling hypothesis predicts a positive coefficient $\left(\beta_{2}\right)$ between debt expectations and the term spread; an orthogonal upward revision in private sector debt expectations leads to a rise in long-term interest rates, implying that the effectiveness of fiscal consolidation in reducing borrowing costs could be diminished in an environment in which economic agents fail to correctly observe (or believe) actual economic fundamentals, underscoring the importance of policy credibility to financial markets. Figure 4 illustrates that, on average, a stronger-than-expected upward revision in private sector expectations of public debt causes implied forward long-term rates to rise above

\footnotetext{
${ }^{10}$ See Refet and Wright (2012), Mankiw, Reis and Wolfers (2003) and Orphanides and Williams (2003).

${ }^{11}$ While typically using monthly financial time series data may attenuate noise and exacerbate issues related to heteroskedasticity, allowing the stochastic volatilities to time-vary helps negate these issues.
} 
any expected change in implied forward short-term rates. Implied forward long-term rates moving in opposite direction to the implied forward short-term rates to a change in expectations conforms to an analytical approach in which implied short-term rates are generally determined according to a Taylor rule, with debt expectations and structural factors affecting implied long-term yields. ${ }^{12}$ In the short-run, this difference in behavior implies that if monetary policy is characterized by strict inflation targeting and does not react to fiscal policy, financial market reaction may accentuate the effect of debt expectation shocks on the real economy. With adjustments in private sector expectations reflected in forward implied long-term rates, Gürkaynak, Sack, and Swanson (2005) note this to imply that the long-run properties of the economy are not constant and known by all agents.

While the changes are quantitatively small, the time-varying estimates reveal material changes in the sensitivity of the term spread to changes in debt expectations. From around 2003 to 2007 , the estimates for all countries show that the relationship between long-run private sector debt expectations and long-term forward rates weakened. This period was marked by falling five-year debt expectations across countries (see Figure 1), a global savings glut, Fed Chairman Greenspan's long-term interest rate 'conundrum', and low macroeconomic volatility. If other advanced economies were affected by these factors the same way the U.S. may have, it would likely represent a coincidental deterioration between debt expectations and interest rates that might be expected across countries. $^{13}$

The decline in the sensitivity of the term spread to debt expectations prior to the GFC is consistent with the fact that macro expectations (including the term spread) became less volatile, which decreased the detectability of any relationship. Likewise, the increase in the coefficient estimates for most countries post-GFC is consistent with an uptick in macroeconomic volatility (see Figure 5). The increased sensitivity of the term spread to debt expectations was more pronounced for the three euro zone countries (France, Germany and Italy) and the U.K. Post-crisis, the cross-country estimates imply that a one percent of GDP upward revision in long-run debt expectations leads to an increase in the implied forward long-term rate from 1.5 to 6.0 basis points over the implied forward short-term rate. These magnitudes are in line with other studies. ${ }^{14}$

\footnotetext{
12 See Evans and Marshall (2002); Gürkaynak, Sack, and Swanson (2005); and Bauer (2011).

${ }^{13}$ The negative coefficient for Japan is consistent with the zero lower-bound policy rate, which covers most of the sample period, and during which attempts were made to lower rates through forward guidance.

${ }^{14}$ See Chinn and Kitchen (2011), Laubach (2009), and Engen and Hubbard (2005) for the U.S.; Kameda (2014) for Japan; Gruber and Kamin (2010) and Silvia, Caselli, and Lane (2006) for advanced economies (including the U.S. and Japan).
} 


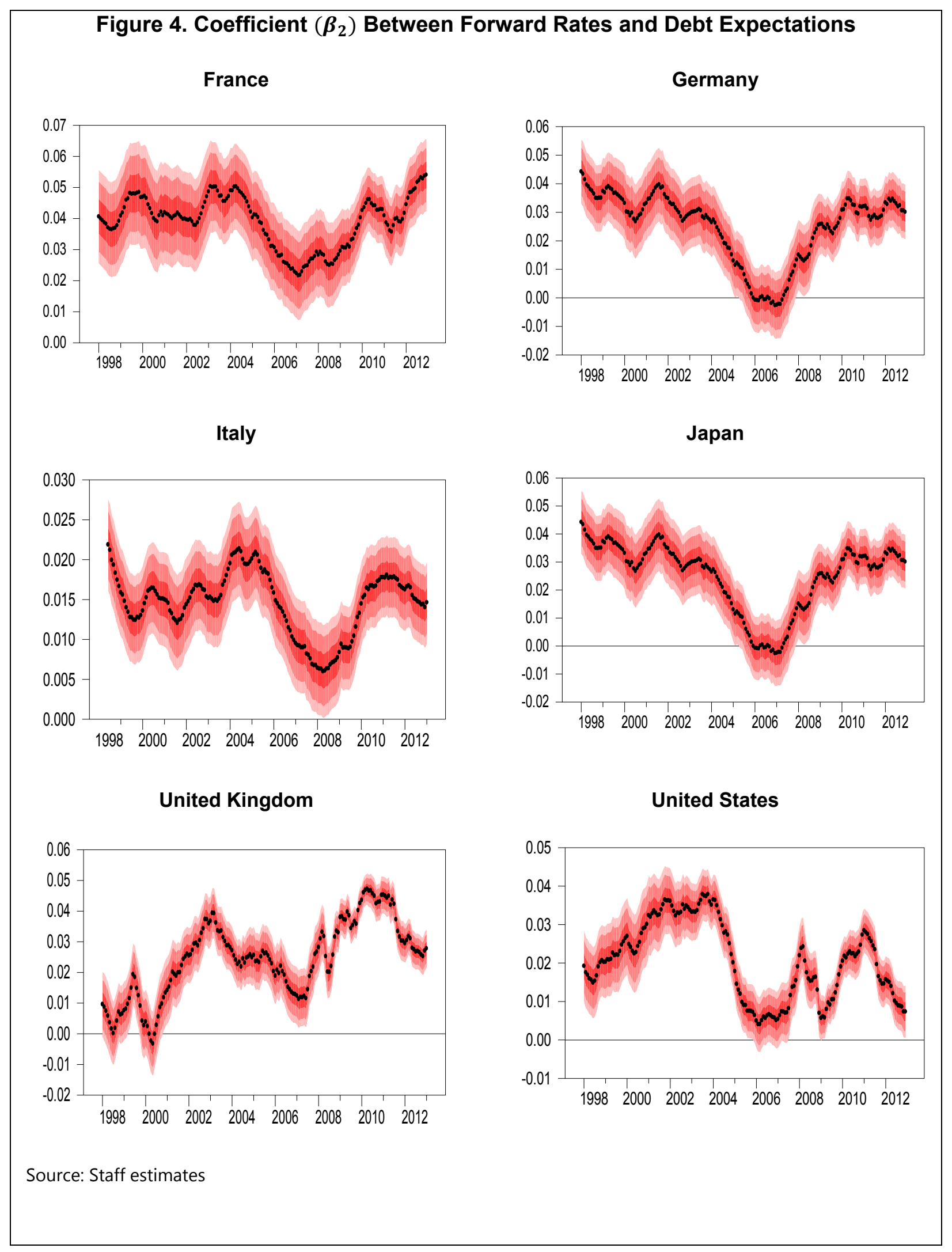

CInternational Monetary Fund. Not for Redistribution 


\section{EXPLAINING MOVEMENTS IN FORWARD INTEREST RATES}

This section uses a multivariate approach to illustrated potential sources of time-variation for the forward term spread with regards to the private sector's broader macroeconomic expectations (including debt). This model fits within the family of autoregressive conditional heteroskedasticity (ARCH) models. Equation (1) is written in stacked form as:

$$
y_{t}=X_{t}^{\prime} \theta_{t}+\varepsilon_{t}
$$

where $y_{t}$ is a vector containing the endogenous variables, $\theta_{t}$ is vector of $5(5 \cdot 1+1)$ in dimension and contains the time-varying reduced-form coefficients $\left(\beta_{i, t}\right)$ and the constant term $\left(\beta_{0, t}\right)$ from equation (1), with $X_{t}=I_{n} \otimes\left[1, y_{t-1}^{\prime}, \ldots, y_{t-p}^{\prime}\right]$, while $\varepsilon_{t}$ is a $n \times 1$ vector of heteroskedastic disturbance terms with zero mean.

A $k \times k$ time-variance covariance matrix is decomposed as:

$$
\operatorname{VAR}\left(\varepsilon_{t}\right) \equiv \Omega_{\mathrm{t}}=\left(A_{t}^{-1}\right) H_{t}\left(A_{t}^{-1}\right)^{\prime}
$$

where the matrix $A_{t}$ is a lower triangular matrix that models the contemporaneous interactions among the endogenous variables $A_{t}=\left[|| 1\left|a_{21}, 1\right|, \ldots,\left|a_{51}, a_{52}, a_{53} a_{54}, 1\right| \mid\right]$. $H_{t}$ is a diagonal matrix that contains the stochastic volatilities, with $H_{t}=\operatorname{diag}\left[h_{1, t}, \ldots, h_{k, t}\right]$. The stochastic volatilities evolve as geometric random walks, independent of one another. They account for the idea that interest rates may be influenced by large infrequent events, as opposed to assuming, as in most models, that movements are driven by small frequent shocks.

The model is estimated using Bayesian methods based on a Metropolis-within-Gibbs sampler. The VAR coefficients are estimated with a flat, uninformative prior, conditional on the draw of $A_{t}$ and $\Omega_{\mathrm{t}}$. The elements of $A_{t}$ is estimated conditional on the VAR coefficients and $\Omega_{\mathrm{t}}$, as in Primaceri (2005). Finally, conditional on the VAR coefficients and $A_{t}$, the $\log$ volatilities are estimated as in Cogley and Sargent (2005). ${ }^{15}$

\footnotetext{
${ }^{15}$ See Rafiq (2014) for full details.
} 


\section{A. Can Debt Expectations Explain the Variance of the Yield Curve}

The process of characterizing stylized facts about economic volatility helps to define the set of questions laid out in Section I. Reinhart and Rogoff (2011) have shown that, historically at least, debt expectations can shift suddenly. This section illustrates changes in the size of growth and debt expectation shocks and their frequency, calculated using the time-varying stochastic volatility estimates, or:

$$
\xi_{t}=\left(\Xi_{t}^{\prime} H_{t} H_{t}^{\prime} \Xi_{t}\right)^{.5}
$$

where $\Xi_{\mathrm{j}}$ is a $k \times 1$ vector with a one in the $j^{\text {th }}$ element and zero elsewhere. The results are illustrated in Figure 6 . The stochastic volatilities are assumed to be orthogonal to one another. Therefore, no a priori reason exists to suppose that shifts in the volatility of interest rates will be correlated with one another. Changes in the size of expectation shocks may be interpreted as 'pure' sunspot shocks that are uncorrelated with changes in underlying macro fundamentals and other expectations. Research shows that higher expectations volatility is associated with periods of greater uncertainty.

A number of commonalities appear from the results:

- Time-varying estimates show that spikes in the size of inflation and growth expectations shocks have tended to coincide across G7 countries.

- $\quad$ Shocks in future debt expectations pre-GFC have often more volatile than innovations in long-term growth expectations. The frequency and size of debt expectation shocks pre-GFC were largest for high debt Italy and Japan.

- $\quad$ Crises lead to large revisions in macroeconomic expectations, including fiscal ones. This observation is in line with the view that fiscal expectations display little inertia during periods of high economic variance.

- $\quad$ Spikes in the size of growth expectations shocks have often coincided with a positive upward tick in the size of debt expectation innovations. Two notable episodes stand out: 2001 and 2008-09 financial market crashes. In the 2008-09 crisis, the rise in the size of debt expectations coincided with an increase in the magnitude of interest rate shocks.

- $\quad$ For all sampled countries, the GFC saw a large spike in the size of risk preference shocks. 


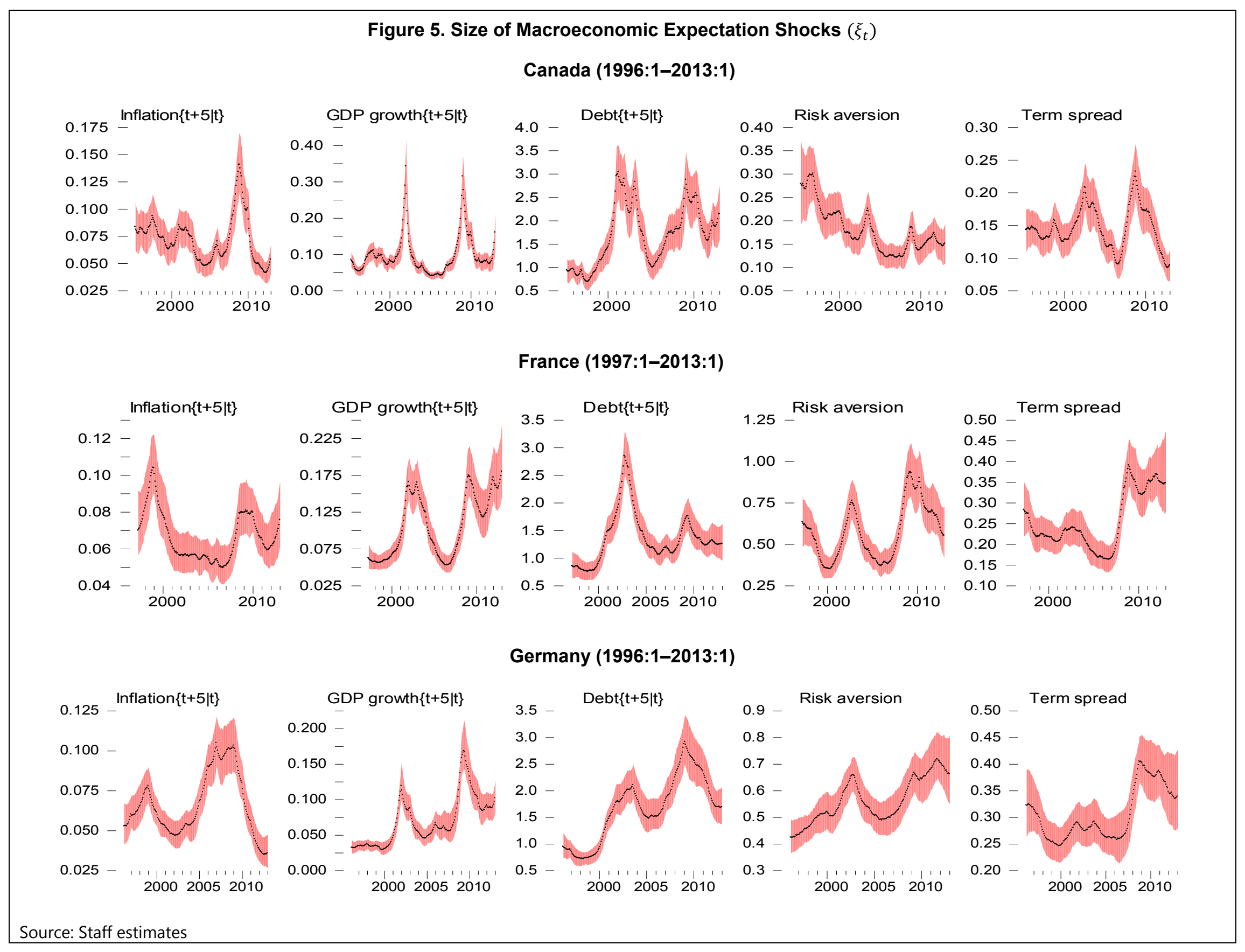

CInternational Monetary Fund. Not for Redistribution 


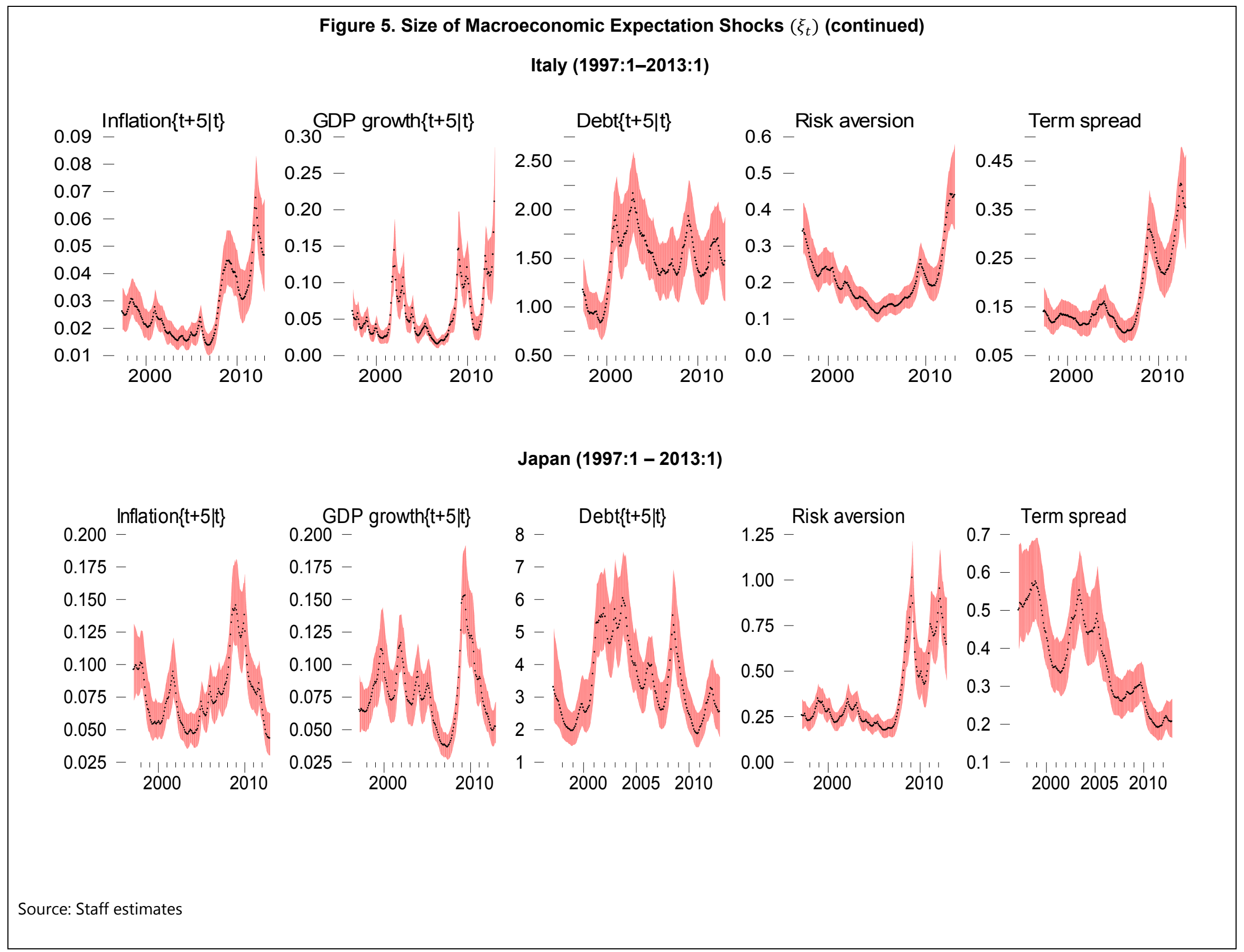

CInternational Monetary Fund. Not for Redistribution 
15

Figure 5. Size of Macroeconomic Expectation Shocks $\left(\xi_{t}\right)$ (continued)

United Kingdom (1996:1 - 2013:1)

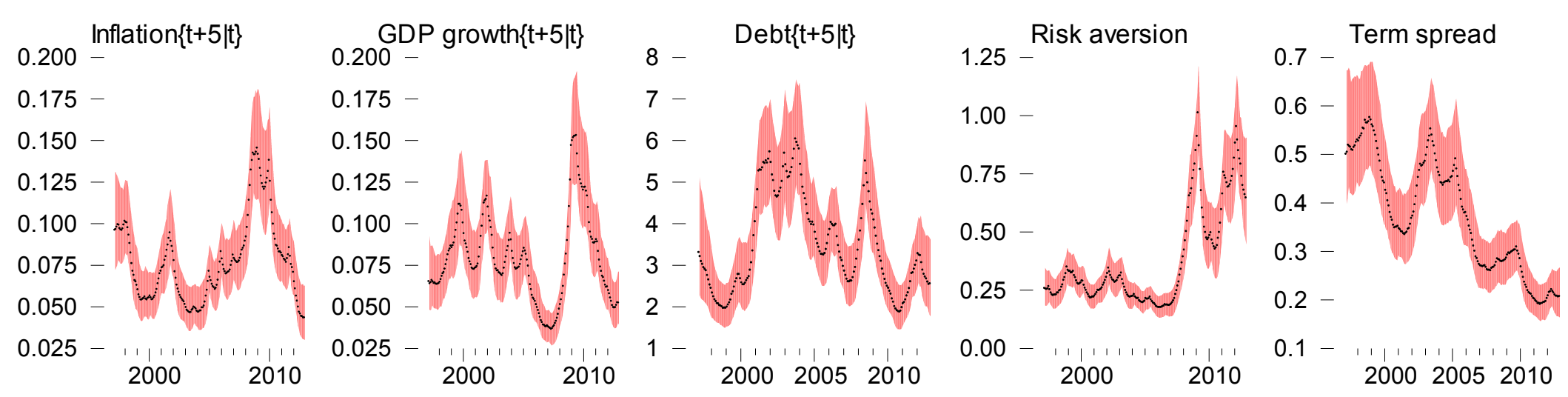

United States (1996:1 - 2013:1)

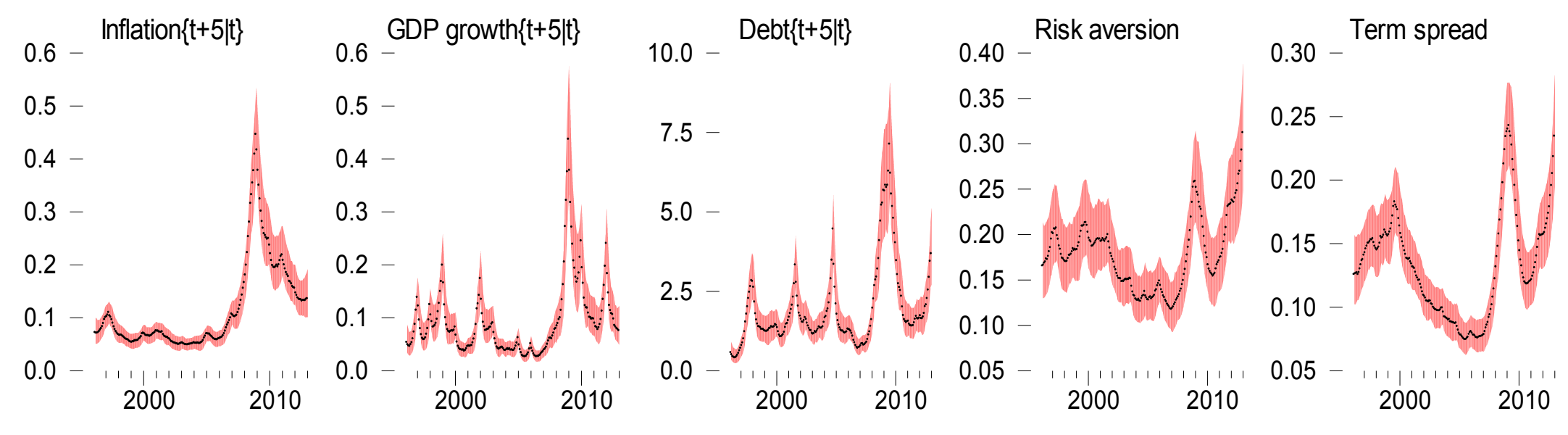

Source: Staff estimates 


\section{B. Information in Private Sector Debt Expectations for Forward Interest Rates}

This section asks whether interest rate movements during and after the GFC resulted in a shift in risk premia ${ }^{16}$ Time-varying variance decomposition estimates are examined, which allow for an assessment of the impact that debt and growth expectations and risk premia had on implied forward rates during specific economic episodes. Wider contours imply larger contributions of shocks in helping forecast interest rate movements. As the forecast horizon increases the error variance converges to the conditional variance implied by the model. Figure 6 (right-hand panel) shows the conditional variance of interest rates, with a number of common findings observed across countries:

- $\quad$ The time-varying estimates show that forward rates are moved by a confluence of shocks at any one particular time.

- $\quad$ Episodes have been observed when expectations have moved in tandem across countries. Coinciding with the recorded high in nominal oil prices observed in mid 2008, the importance of inflation expectations in the years preceding the GFC rose for most countries.

- The estimates for the U.S., as well as for Italy, Japan and the U.K, show that a significant proportion of the rise in interest rate volatility during 2008-09 was due to growth expectation shocks. The rise in the relative importance of growth expectations for U.S long-term rates is also evident in the notion that, with shortterm interest rates constrained by the zero lower bound (ZLB), long-term rates reflect a one-way bet driven by fluctuating optimism over economic growth; greater confidence would be expected to push short-term interest rates above the ZLB and increase long-term rates.

- If the willingness of investors to bear risk is not steady, financial theory suggests that risk premia should vary with the business cycle. Shocks in risk aversion became more important in explaining long-term implied forward rates post-crisis for all countries. For the U.S., this finding is in line with the portfolio balance approach, which predicts large crises lead to safe heaven money flows, turning U.S. term premia negative. In the case of Italy, the crisis led to capital reversing flows, which raised risk premia.

The time-varying estimates for non-euro zone countries show that, whether pre- or postcrisis, the relative information content contained in long-run private sector debt expectations for forward rates has been, at best, modest over the sample. ${ }^{17}$ The U.S. estimates in Figure 6 show that from 2003, the information contained in private sector debt expectations for forward rate rose, explaining around 15 percent of the variation in forward rates in 2007. Following the crisis in 2008-09, the explanatory power of long-run private sector debt expectations declined. For Japan, the rise in the explanatory power of debt expectations for interest rates during the early-to-mid 2000s is consistent with evidence in Koo (2009) and Rafiq (2012), which noted heightened fiscal concerns on the

\footnotetext{
${ }^{16}$ See Cochrane (2011).

${ }^{17}$ See Engen and Hubbard (2005).
} 
part of policymakers during this time. Nonetheless, as with the U.S., much of the variation in interest rates in Japan after the GFC is attributable to revisions in growth expectations and risk aversion. ${ }^{18}$ Finally, similar to the U.S. and Japan, the statedependent estimates for Canada and the U.K. show that shocks to growth and inflation expectations and risk aversion have been more important for forward rates than debt expectations.

For two euro zone countries, France and Italy, the information contained within movements in debt expectations for long-term rates were significant in the years preceding the GFC. However, post crisis, the explanatory power of long-run private sector debt expectations has declined at the expense of innovations in long-run growth expectations and shocks in risk aversion. The rise in the explanatory power of the equity premium for the term spread is in line with Cochrane (2011), which noted that variations in the discount rate for government debt (as proxies shifting investor preference) were prominent in driving rates post-GFC. The results for Italy suggest the rise in interest rates post-crisis was due to a decline in the willingness of investors to bear risk, leading to rising discount and interest rates, as reflected in elevated term premia.
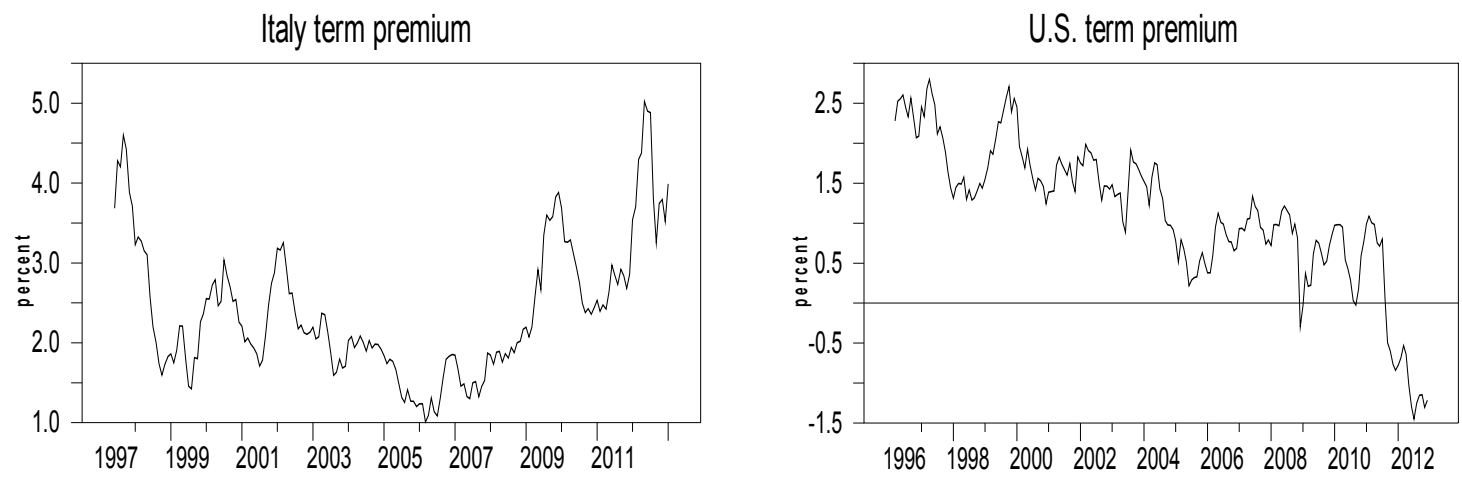

Source: Staff calculations.

Finally, the modest explanatory power of medium-term inflation expectations for interest rates post-GFC for all G7 countries contrast with predictions made under the fiscal theory of the price level, which links concerns over future inflation to the ratio of public debt. The evidence also implies that the real impact of a change in fiscal policy post-crisis is not likely to have been transmitted through the expected inflation channel. ${ }^{19}$

A few caveats are worth noting. First, it is difficult to determine whether debt expectations extracted from a qualitative survey data reflect 'pure' shifts in private sector public debt expectations five years hence.

\footnotetext{
18 The stochastic volatilities in Figure 5 reported a large rise in the size of growth and risk aversion shocks for the U.S. and Japan during this period

${ }^{19}$ See Dupor and Li (2013).
} 


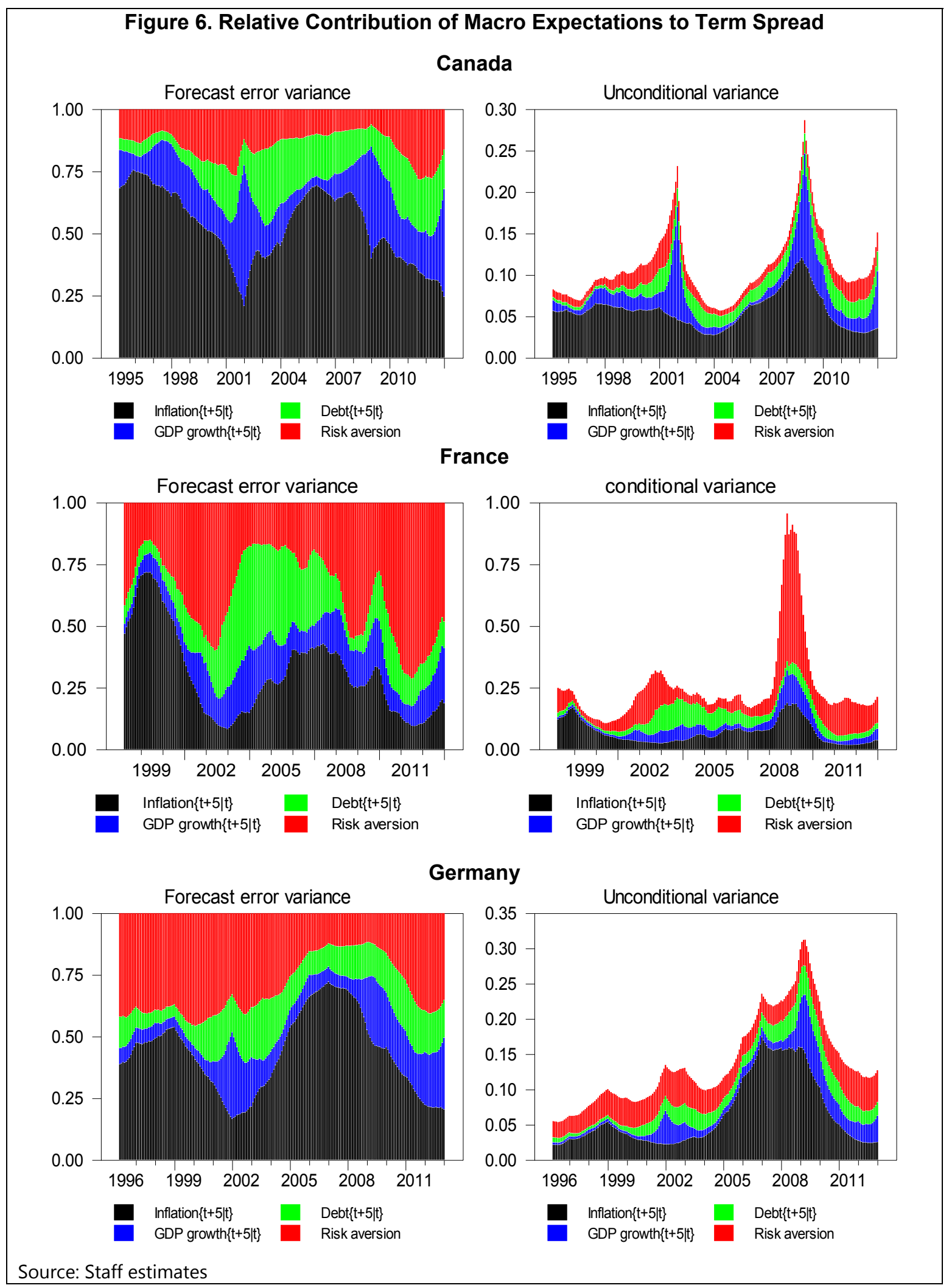

CInternational Monetary Fund. Not for Redistribution 
Figure 6. Relative Contribution of Macro Expectations to Term Spread (continued) Italy
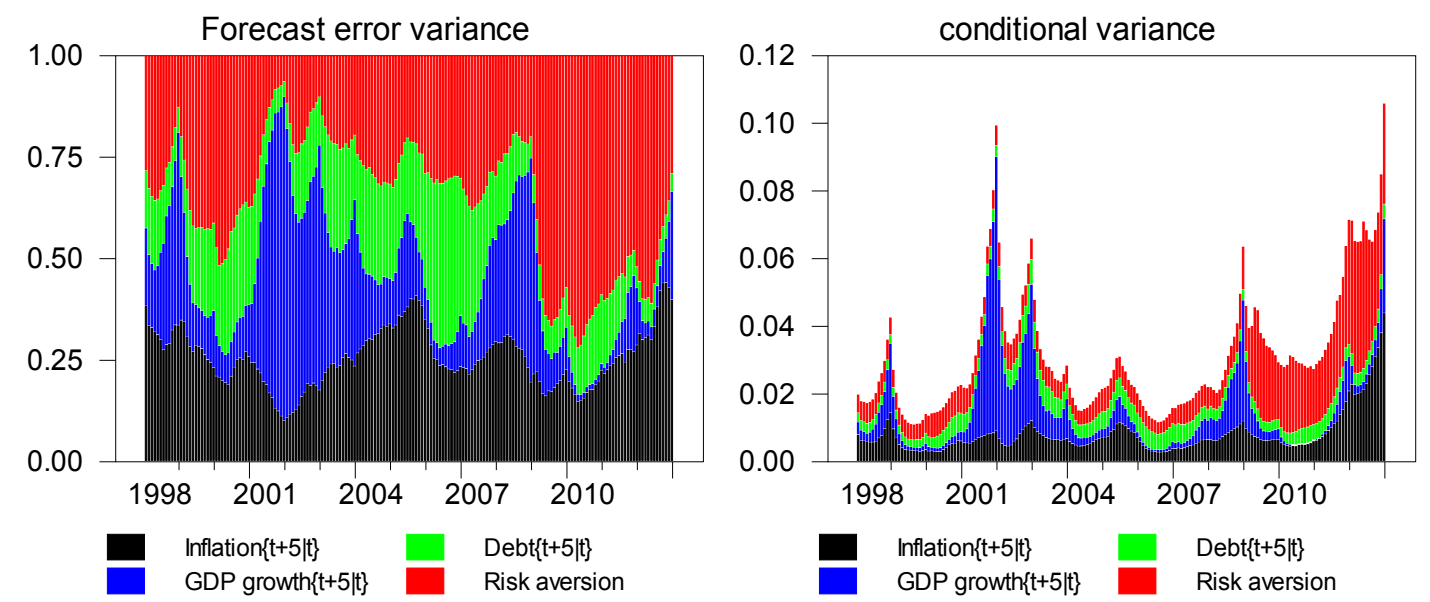

Japan
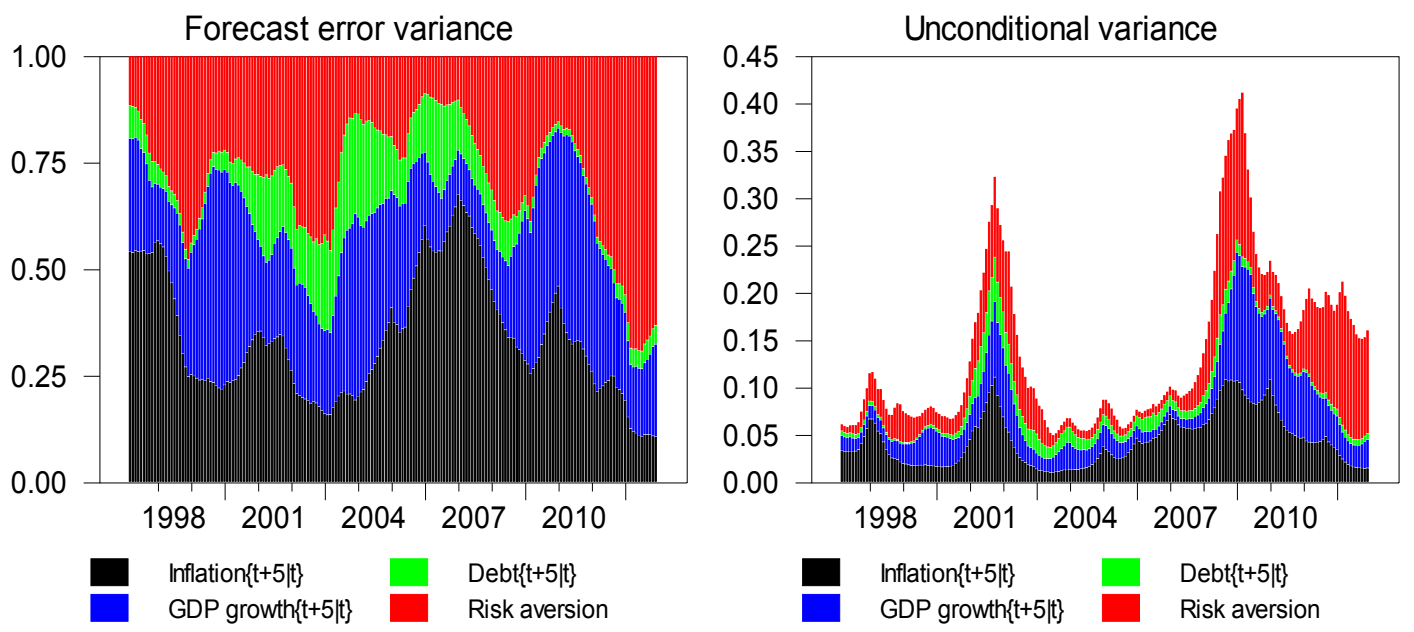

United Kingdom
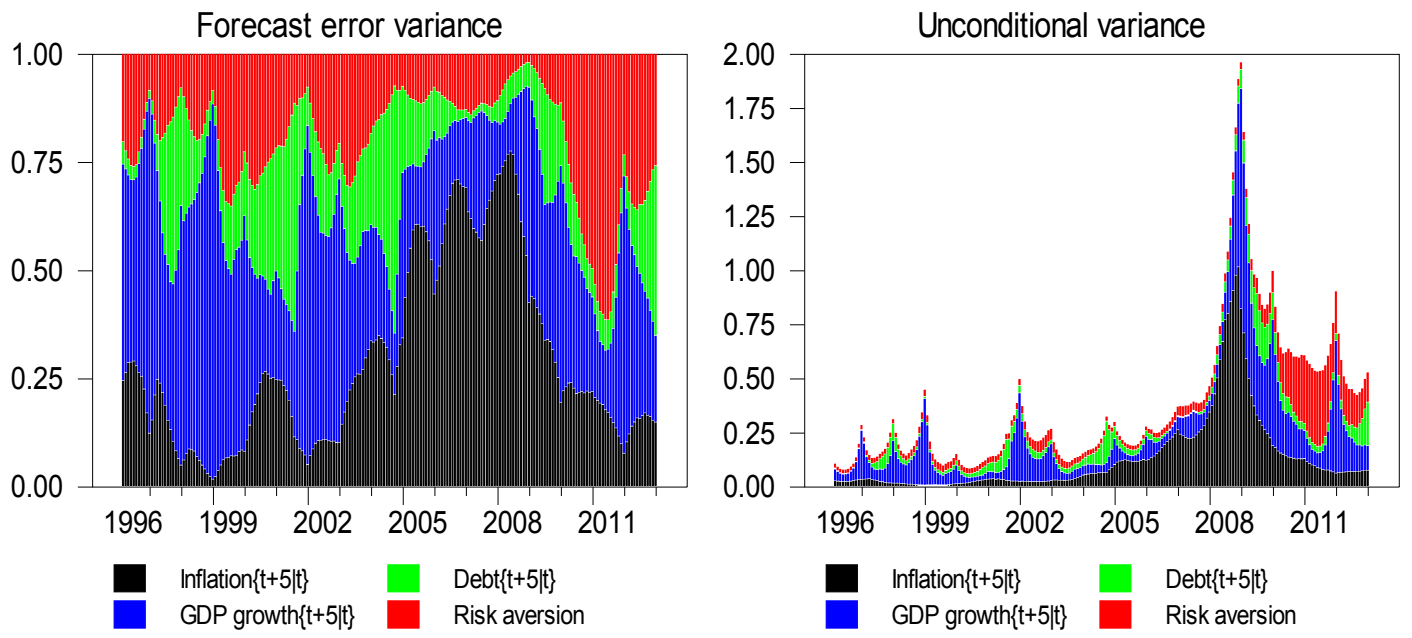

Source: Staff estimates 


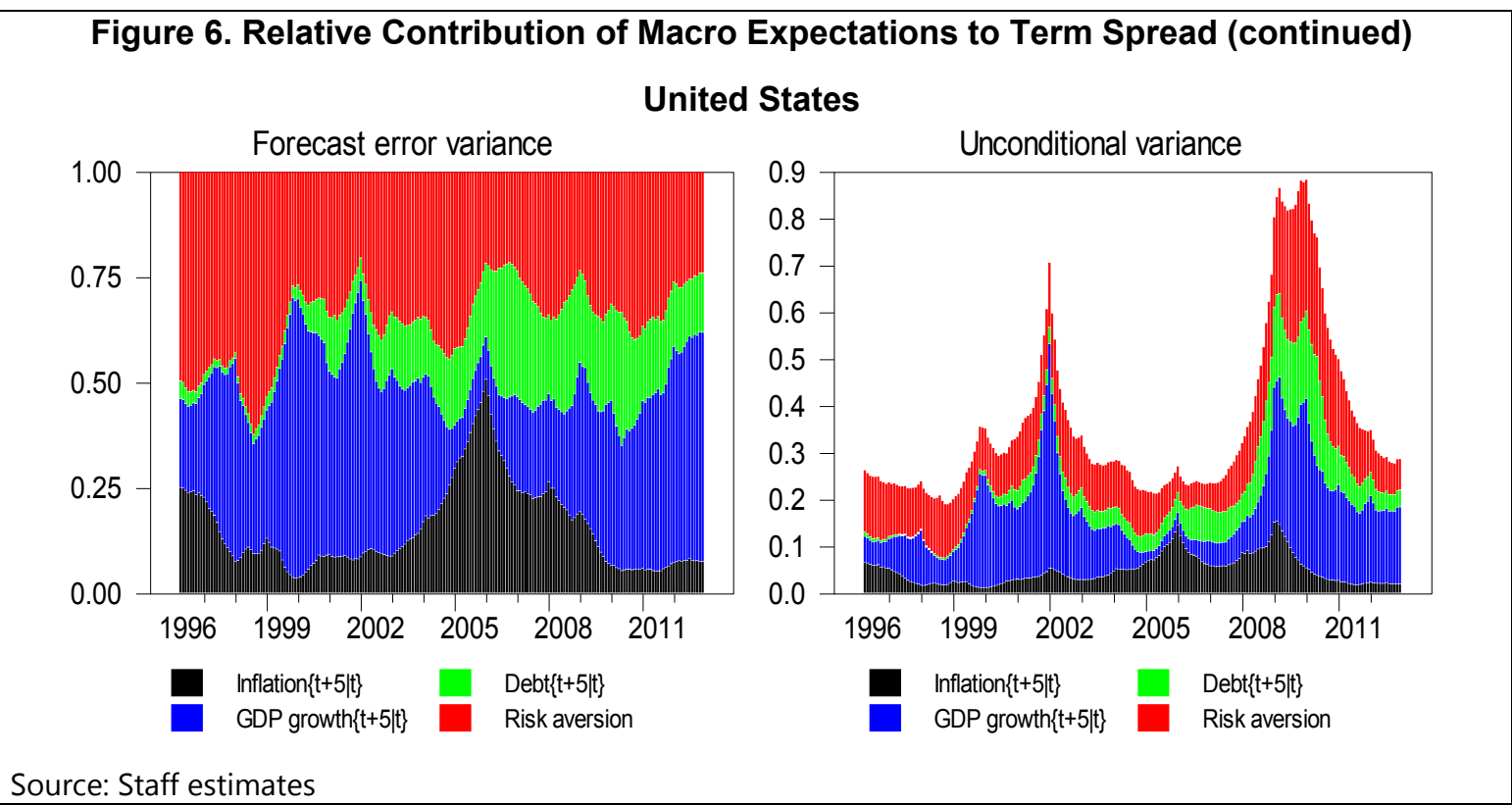

Second, since it is unlikely that a structural model will incorporate all the information available to agents when debt expectations are being formed, little agreement exists over whether shocks to expectations may be the result of unforecastable movements in expectations resulting from changes in omitted fundamentals or pure sunspot shocks. In this instance, omitted variables may reflect factors such as policy communication or other variables that affect private sector fiscal expectations.

\section{SUMMARY}

This paper has shown that shifts in growth expectations and in risk aversion appear to have been a more significant than fiscal expectations in explaining fluctuations in longterm interest rates following the GFC. This is in line with crisis literature, which cites fluctuating price of risk as a key cause behind financial crises. However, the findings here should not be construed as implying that debt does not matter. Long-run private sector debt expectations manifest themselves at the longer end of the yield curve in a small but significant magnitude, highlighting the importance of fiscal consolidation plans being seen as credible by private agents. Policies that influence long-run growth expectations are, nonetheless, more important than projected fiscal outturns in driving long-term government borrowing costs for most G7 countries.

When interpreting these results, it is important to keep in mind that qualitative survey reports of expectations are not reflective of market actions. Since financial market participants dictate the flow of funds into bond markets, greater faith has often been placed in estimates taken from financial market data, even while recognizing the problems associated with extracting expectations from such data. Nonetheless, additional study and comparison of both sources of expectations data are needed to form a more complete picture of the properties of fiscal expectations. 


\section{Appendix A. Linking the Term Spread and Fiscal Position}

Kitchen (2002) outlines a simple model beginning with a simple Taylor rule that links interest rates to a measure of real output and inflation

$$
i_{t}^{1}=E_{t} \pi_{t+1}+r_{t}^{*}+\alpha\left(\pi_{t}-\pi_{t}^{*}\right)+\beta\left(y_{t}-y_{t}^{*}\right)
$$

where $i_{t, 1}^{1}$ is the short-term nominal interest rate in period $t ; r_{t}^{*}$ present the value of the real interest rate that would prevail in the absence of nominal rigidities; $\pi_{t}$ is inflation and $\pi_{t}^{*}$ denotes the inflation target; $y_{t}$ is a measure of real output and $y_{t}^{*}$ is a measure of potential output.

By extrapolating expectations sufficiently far into the future

$$
E_{t} \pi_{t+k}=\pi^{*}
$$

Since $r_{t}^{*}$ is outside the control of monetary policy, the expected short-term rate expected to prevail sufficiently far into the future equates to

$$
E_{t} i_{t+k}^{1}=E_{t} \pi_{t+k}^{*}
$$

This helps negate having to model the level short-term interest rate explicitly.

Following Kitchen and Chinn (2011), the spread between the long-term $\left(i_{t}^{5}\right)$ and shortterm interest rate can be expressed as

$$
i_{t}^{5}-i_{t}^{1} \approx \frac{\left(i_{t, 1}+E_{t} i_{t+5}^{1}\right)}{5}+\sigma_{t, 5}-i_{t}^{1}
$$

where $\sigma_{t}$ is the term premium set in period $t$ for the five year horizon. This is consistent with standard asset pricing theory which implies that long horizon interest rates are equal to some risk premium plus the expected short-term interest rate. For the purposes of this paper the term premium is defined as

$$
\sigma_{t}=\gamma_{t}+\mu_{t}
$$

where $\gamma_{t}$ is a risk premium resulting from financial uncertainty associated with a deteriorating fiscal position, and $\mu_{t}$ is a term capturing other unidentified risk factors. Combining equations (A.1) to (A.4)

$$
i_{t}^{5}-i_{t}^{1}=-\pi_{t}-y_{t}+\gamma_{t}+\mu_{t}
$$

The model implies that short-term rates are determined by the monetary policy rule, whereas changes in the supply and demand for public debt show up in the long-end of the yield curve. The equation (A.4) shows that the spread between the long- and short-term interest rate is a function of inflation, real output, a risk premium associated with the public sector fiscal position. 


\section{Appendix B. Data Sources}

\begin{tabular}{|c|c|c|c|c|c|}
\hline & $\begin{array}{c}\text { Five year } \\
\text { inflation } \\
\text { expectations }\end{array}$ & $\begin{array}{c}\text { Five year } \\
\text { GDP } \\
\text { expectations }\end{array}$ & $\begin{array}{c}\text { Five year } \\
\text { debt } \\
\text { expectations }\end{array}$ & $\begin{array}{l}\text { Equity } \\
\text { Premium }\end{array}$ & $\begin{array}{c}\text { Implied } \\
\text { forward rates }\end{array}$ \\
\hline $\begin{array}{l}\text { Canada } \\
(1997: 1- \\
2013: 1)\end{array}$ & $\begin{array}{c}\text { Consensus } \\
\text { forecast }\end{array}$ & $\begin{array}{c}\text { Consensus } \\
\text { forecast }\end{array}$ & EIU & $\begin{array}{l}\text { Yield earnings } \\
\text { S\&P/TSX } \\
\text { index } \\
\text { (Datastream) }\end{array}$ & $\begin{array}{l}\text { Constructed } \\
\text { using nominal } \\
\text { yields from } \\
\text { DLX Haver }\end{array}$ \\
\hline $\begin{array}{l}\text { France } \\
(1997: 1- \\
2013: 1)\end{array}$ & $\begin{array}{c}\text { Consensus } \\
\text { forecast }\end{array}$ & $\begin{array}{c}\text { Consensus } \\
\text { forecast }\end{array}$ & EIU & $\begin{array}{l}\text { Yield earnings } \\
\text { CAC } 40 \\
\text { (Datastream) }\end{array}$ & $\begin{array}{l}\text { Constructed } \\
\text { using nominal } \\
\text { yields from } \\
\text { DLX Haver }\end{array}$ \\
\hline $\begin{array}{l}\text { Germany } \\
(1997: 1- \\
2013: 1)\end{array}$ & $\begin{array}{c}\text { Consensus } \\
\text { forecast }\end{array}$ & $\begin{array}{c}\text { Consensus } \\
\text { forecast }\end{array}$ & EIU & $\begin{array}{l}\text { Yield earnings } \\
\text { DAX } 30 \\
\text { (Datastream) }\end{array}$ & $\begin{array}{l}\text { Constructed } \\
\text { using nominal } \\
\text { yields from } \\
\text { DLX Haver }\end{array}$ \\
\hline $\begin{array}{l}\text { Italy } \\
(1997: 1- \\
2013: 1)\end{array}$ & $\begin{array}{c}\text { Consensus } \\
\text { forecast }\end{array}$ & $\begin{array}{c}\text { Consensus } \\
\text { forecast }\end{array}$ & EIU & $\begin{array}{l}\text { Yield earnings } \\
\text { MIB } 100 \\
\text { (Datastream) }\end{array}$ & $\begin{array}{l}\text { Constructed } \\
\text { using nominal } \\
\text { yields from } \\
\text { DLX Haver }\end{array}$ \\
\hline $\begin{array}{l}\text { Japan } \\
(1997: 1- \\
2010: 1)\end{array}$ & $\begin{array}{c}\text { Consensus } \\
\text { forecast }\end{array}$ & $\begin{array}{c}\text { Consensus } \\
\text { forecast }\end{array}$ & EIU & $\begin{array}{l}\text { Yield earnings } \\
\text { Nikkei } 225 \\
\text { (CEIC) }\end{array}$ & $\begin{array}{l}\text { Constructed } \\
\text { using nominal } \\
\text { yields from } \\
\text { DLX Haver }\end{array}$ \\
\hline $\begin{array}{l}\text { United } \\
\text { Kingdom } \\
(1996: 1- \\
2013: 1)\end{array}$ & $\begin{array}{c}\text { Consensus } \\
\text { forecast }\end{array}$ & $\begin{array}{c}\text { Consensus } \\
\text { forecast }\end{array}$ & EIU & $\begin{array}{l}\text { Yield earnings } \\
\text { FTSE } 100 \\
\text { (Datastream) }\end{array}$ & $\begin{array}{l}\text { Bank of } \\
\text { England }\end{array}$ \\
\hline $\begin{array}{l}\text { United } \\
\text { States } \\
(1996: 1 \text { - } \\
2013: 1)\end{array}$ & $\begin{array}{c}\text { Consensus } \\
\text { forecast }\end{array}$ & $\begin{array}{c}\text { Consensus } \\
\text { forecast }\end{array}$ & EIU & $\begin{array}{l}\text { Yield earnings } \\
\text { S\&P } 500 \\
\text { (Datastream) }\end{array}$ & $\begin{array}{c}\text { FRED } \\
\text { database }\end{array}$ \\
\hline
\end{tabular}




\section{Appendix C. Time-varying Regression Estimation}

The prior density $(\pi)$ for a vector of variables $(\theta)$ obtains the posterior distribution $\pi(\theta, \beta, h \mid y)$. The Markov Chain Monte Carlo simulation is based on the following steps:

(1) Initialize $\theta, \beta$ and $h$

(2) Sample $\beta \mid \gamma, Q, h, y$

(3) Sample $Q \mid \beta$

(4) Sample $h \mid \beta, \lambda, Q, \sigma_{\xi}, \psi$

(5) Sample $\psi \mid \beta$

(6) Sample $\sigma_{\xi} \mid \beta$

(7) Sample $\lambda \mid \beta, h, y$

(8) Go to step (2)

\section{Sampling $\beta$}

A simulation smoother as in Durbin and Koopman (2002) is used to sample $\beta$ simultaneously from the Kalman filter and simulation smoother. This helps reduce the autocorrelation in the MCMC sample. The conditional posterior distribution is expressed as $\pi(\beta \mid Q, \xi . h, y)$. See Durbin and Koopman (2002) for full details.

\section{Sampling $Q$}

The derivation of the conditional posterior distribution for $Q(\pi(Q \mid \beta))$ follows Nakajima (2012). Samples are drawn from an inverse-Wishart conditional distribution, $Q \mid \beta \sim$ $\operatorname{IW}\left(\hat{q}, \widehat{\Omega}^{-1}\right)$, where

$$
\widehat{q}=q_{0}+n-1 \text { and } \widehat{\Omega}=\Omega_{0}+\sum_{t=1}^{n-1}\left(\beta_{t+1}-\beta_{t}\right)\left(\beta_{t+1}-\beta_{t}\right)^{\prime}
$$

\section{Sampling $\boldsymbol{h}_{\boldsymbol{t}}$}

The stochastic volatilities are estimated using a multi-move sampler. See Shephard and Pitt (1997) for full details.

\section{Sampling $\lambda$}

A candidate draw from a truncated normal distribution is made such that $\lambda^{*} \sim T N_{[-1,1]}\left(\mu_{\lambda}, \sigma_{\lambda}^{2}\right)$, where

$$
\mu_{\lambda}=\frac{\sum_{t=1}^{n-1} h_{t} h_{t+1}}{\sum_{t=2}^{n-1} h_{t}^{2}}, \quad \sigma_{\lambda}^{2}=\frac{\sigma_{\xi}^{2}}{\sum_{t=2}^{n-1} h_{t}^{2}}
$$

The acceptance rates for candidate draw $\lambda^{*}$ from $\lambda_{0}$, denoted $v\left(\lambda_{0}, \lambda^{*}\right)$ is given by

$$
v\left(\lambda_{0}, \lambda^{*}\right)=\min \left\{1, \frac{\pi\left(\lambda^{*} \mid \sigma_{\xi}, h\right) d\left(\lambda_{0}\right)}{\pi\left(\lambda_{0} \mid \sigma_{\xi}, h\right) d\left(\lambda^{*}\right)}\right\}
$$


where $d(\lambda)$ is the probability density function. The acceptance rate is the ratio of the terms omitted from the conditional posterior distribution. The acceptance is determined by whether $u<v\left(\lambda_{0}, \lambda^{*}\right)$, where $u \sim N(0,1)$ is uniform random number.

\section{Sampling $\sigma_{\xi}$}

The prior of $\sigma_{\xi}$ is set from an inverse gamma distribution $\sigma_{\xi}^{2} \sim I G\left(\frac{q_{0}}{2}, \frac{s_{0}}{2}\right)$, where

$$
\hat{q}=q_{0}+n \quad \text { and } \quad \hat{s}=s_{0}+\left(1-\lambda^{2}\right) h_{1}^{2}+\sum_{t=1}^{n-1}\left(h_{t+1}-\lambda h_{t}\right)^{2}
$$

Samples are drawn from the conditional distribution $\sigma_{\xi} \mid \lambda, h \sim \operatorname{IG}\left(\frac{\hat{q}}{2}, \frac{\hat{s}}{2}\right)$.

\section{Sampling $\xi$}

Sampling $\xi$ is implemented in the sample way as the sampling of $\sigma_{\xi}$. The prior is set so that $\xi \sim I G\left(\frac{\xi_{0}}{2}, \frac{W_{0}}{2}\right)$. The conditional distribution for $\xi$ is given by $\xi \mid h \sim I G\left(\frac{\hat{\xi}}{2}, \frac{\widehat{W}}{2}\right)$, where

$$
\hat{\xi}=\xi_{0}+n \quad \text { and } \quad \widehat{W}=W_{0}+\sum_{t=1}^{n}\left(y_{t}-x_{t}^{\prime} \beta\right)^{2} / \varepsilon^{h t}
$$

See Nakajima and Teranishi (2009) for full details. 


\section{REFERENCES}

Ardagna, S., F. Caselli and T. Lane (2006), 'Fiscal discipline and the cost of public debt service: Some estimates for the OECD countries', The B.E. Journal of Macroeconomics, 7(1): 1-27.

Bauer, M. (2011), 'What Moves the Interest Rate Term Structure?', FRBSF Economic Letters, 34-2011.

Baumeister, C. and L. Benati (2013), 'Unconventional Monetary Policy and the Great Recession: Estimating the Macroeconomic Effects of a Spread Compression at the Zero Lower Bound', International Journal of Central Banking, 9(2): 166-212

Bernanke, B. S, V. R. Reinhart and B. P. Sack (2004), 'Monetary Policy Alternatives at the Zero Bound: An Empirical Assessment', Brookings Papers on Economic Activity, 2: 1-78

Bernanke, B. S. (2013), 'Long-Term Interest Rates', Remarks by Ben S. Bernanke Annual Monetary/Macroeconomics Conference: The Past and Future of Monetary Policy', Federal Reserve Bank San Francisco.

Carroll, C. D. (2001), 'The Epidemiology of Macroeconomic Expectations', NBER Working Paper Number 8695.

Carroll, C. D. (2003), 'Macroeconomic Expectations Of Households And Professional Forecasters', The Quarterly Journal of Economics, 118(1): 269-298

Cochrane, J. (1998), ‘A frictionless view of U.S. Inflation', in B. S. Bernanke and J. Rotemberg (eds.), NBER Macroeconomics Annual 1998, pp: 323-421.

Cochrane, J. (2011), 'Presidential Address: Discount Rates', Journal of Finance, 66(4): $1047-1108$.

Cogley, T. and T. J. Sargent (2005), 'Drifts and Volatilities: Monetary Policies and Outcomes in the Post WWII US', Review of Economic Dynamics, 8: 262 - 302.

Durbin, J. and S. J. Koopman (2002), 'A simple and efficient simulation smoother for state space time series analysis', Biometrika, 89(3): 603-616.

Elmendorf, D. W., and N. G. Mankiw (1999),'Government Debt', in J. B. Taylor and M. Woodford (eds.), Handbook of Macroeconomics, Vol. 1, Amsterdam: Elsevier Science 1999.

Engen, E. and G. Hubbard (2005), 'Federal Government Debt and Interest Rates', NBER Macroeconomics Annual 2004, Vol. 19, ed. M. Gertler and K. Rogoff, pp: 84138. 
Evans, C. L. and D. A. Marshall (2002), 'Economic determinants of the nominal treasury yield curve', Federal Reserve Bank of Chicago.

Feldstein, M. (1986), 'Budget Deficits, Tax Rules and Real Interest rates', NBER Working Paper No. 1970.

Friedman, B. N. (1979), 'Interest Rate Versus Forward Rates: Evidence from an Expectations Survey', Journal of Finance, XXXIV(4): 965-973.

Gale, W. and P. Orszag (2002), 'The economic effects of long-term fiscal discipline', Brookings Institution.

Gordon, M. (1962), Investment, Financing and Valuation of the Corporation, Homewood, IL: R. D. Irwin.

Gürkaynak, R., B. Sack and E. Swanson (2005), 'The Sensitivity of Long-Term Interest Rates to Economic News: Evidence and Implications for Macroeconomic Models', American Economic Review, 95(1): 425-436.

Gürkaynak, R. S., B. P Sack and E. T Swanson (2007), 'Market-based measures of monetary policy expectations', Journal of Business and Economic and Statistics, 25(2): 201-212.

Gürkaynak, R. S. and J. H. Wright (2012), 'Macroeconomics and the Term Structure', Journal of Economic Literature, 50(2): 331-67.

Gruber, J. W. and S. B. Kamin (2010), 'Fiscal positions and government bond yields in OECD countries' Board of Governors of the Federal Reserve System, International Finance Discussion Paper Number 101.

Krishnamurthy, A. and A. Vissing-Jorgensen (2012), 'The Aggregate Demand for Treasury Debt', Journal of Political Economy, 120(2): 233-267.

Kitchen, J. (2002), ‘A note on interest rates and structural federal budget deficits', U.S. Congress, House of Representatives, Budget Committee, October.

Kitchen, J. and M. Chinn (2011), 'Financing US Debt: Is There Enough Money in the World - and at What Cost?', International Finance, 14(3): 372-413.

Koo, R. (2009), The Holy Grail of Macroeconomics, John Wiley and Sons.

Laubach, T. (2003), 'New evidence on the interest rate effects of budget deficits and debts', Board of Governors of the Federal Reserve System, Financial and Economics Discussion Series 2003-12, May.

Leduc, S., Sill, K. and T. Stark (2007), 'Self-fulfilling expectations and the inflation of the 1970s: evidence from the Livingston Survey', Journal of Monetary Economics, 54: 433-359. 
Mankiw, N. G. and R. Reis. (2002), 'Sticky information versus sticky prices: A proposal to replace the new Keynesian Phillips curve', Quarterly Journal of Economics, 117(4): 129-132.

Mankiw, N. G. , R. Reis, J. Wolfers (2003), 'Disagreement About Inflation Expectations', NBER Macroeconomics Annual 2003, ed. Mark Gertler and Kenneth Rogoff, pp. $209-270$.

Nakajima, J. and Y. Teranishi (2009), 'The Evolution of Loan Rate Stickiness across the Euro Area', IMES Discussion Paper No. 2009-E-10, Institute for Monetary and Economic Studies, Bank of Japan.

Orphanides, A. and J. C. Williams (2003), 'Imperfect Knowledge, Inflation Expectations, and Monetary Policy’, NBER Working Paper No. 9884

Primiceri, G. E. (2005), 'Time Varying Structural Vector Autoregressions and Monetary Policy', Review of Economic Studies, 72: 821-852.

Rafiq, S. (2014), 'What Do Energy Prices Tell Us About UK Inflation?', Economica, 81: $293-310$.

Reinhart, C. M., and K. S. Rogoff (2011), 'From Financial Crash to Debt Crisis', American Economic Review, 101(5): 1676-1706. 